\title{
Population analysis of Scomberomorus cavalla (Cuvier, 1829) (Perciformes, Scombridae) from the Northern and Northeastern coast of Brazil
}

\author{
Santa Brígida, EL., Cunha, DB., Rego, PS., Sampaio, I., Schneider, H. and Vallinoto,M.* \\ Laboratório de Genética e Biologia Molecular, Instituto de Estudos Costeiros - IECOS, \\ Campus de Bragança, Universidade Federal do Pará - UFPA, \\ Alameda Leandro Ribeiro, sn, CEP 68600-000, Aldeia, Bragança, PA, Brazil \\ *e-mail: mvallino@ufpa.br
}

Received May 30, 2007 - Accepted August 30, 2007 - Distributed December 1, 2007

(With 3 figures)

\begin{abstract}
Scomberomorus cavalla is a pelagic fish species widely distributed on the Atlantic west coast, and a noticeable decrease in its capture level in the USA and Gulf of Mexico is occurring, compared to the levels reached by the species in the past. Likewise, in some areas of Brazil, there has been indication of over-harvesting. However, there are no molecular studies focusing on the management of such an important item. Thus, in the present study, 380 nucleotide base pairs of the mitochondrial DNA D-Loop region of samples from Macapá, Bragança, and Fortaleza were sequenced. Phylogenetic and population analyses revealed that there is only one panmitic population, and low levels of genetic variability were verified. These results, as well as the noticed over-harvesting of $S$. cavalla, represent very important data to determine the management of such stock in order to prevent a collapse or the risk of future extinction.
\end{abstract}

Keywords: Scomberomorus cavalla, D-loop, population analysis.

\section{Análise populacional de Scomberomorus cavalla (Cuvier, 1829) (Perciformes, Scombridae) da costa Norte e Nordeste brasileira}

\begin{abstract}
Resumo
Scomberomorus cavalla é uma espécie de peixe pelágico amplamente distribuído na costa oeste do Atlântico, e uma diminuição no seu nível de captura tem sido verificada nos E.U.A e Golfo do México, comparada com os níveis alcançados pela espécie no passado. Da mesma forma, em algumas áreas do Brasil, há indícios de sobre-exploração. Entretanto, não existem estudos moleculares que visam o manejo deste importante item. Desta forma, no presente estudo, foram seqüenciados 380 pares de bases nucleotídicas da região da Alça-D do DNA mitocondrial de amostras provenientes de desembarque em Macapá, Bragança e Fortaleza. As análises filogenéticas e populacionais revelaram que há apenas uma população panmítica e baixos níveis de variabilidade genética foram observados. Estes resultados, assim como a observada sobre-exploração de $S$. cavala, representam dados muito importantes para o estabelecimento do manejo deste estoque a fim de prevenir um colapso ou risco de extinção no futuro.
\end{abstract}

Palavras-chave: Scomberomorus cavalla, alça-D, análise populacional.

\section{Introduction}

Scomberomorus cavalla (Cuvier, 1829), commonly known as cavalla or king mackerel, is a pelagic fish species widely distributed along the West Atlantic. It is distributed from Massachusetts, USA, all the way to Santa Catarina State, in Brazil, and it is restricted to coastal waters closer to the ocean (Collete and Nauen, 1983; Cervigón et al., 1993; Fonteles-Filho, 1998; CarvalhoFilho, 1999). This species has a great importance for recreational and commercial fishing along the southwestern portion of the USA and Gulf of Mexico (Deuel and Clark, 1968; Deuel, 1973; Manooch, 1979).
Commercial fishing of this item has been carried out since the 1880's in the USA and Gulf of Mexico. In this latter region, during the 1970's decade, the king mackerel was considered to be in over-fished status. Management actions taken by governmental institutions since 1983 contributed for the species recovery levels of abundance that are necessary for a sustainable yield in fishing production; the actual abundance level is high enough so the agencies in charge of fishing management in the Gulf do not currently rate it as in over-fished status (See Gold and De Vries, 2002). 
For a long time, the northeastern region of Brazil delivered the highest output of $S$. cavalla and $S$. brasiliensis Collette, Russo and Zavala-Camin, 1978 (serra Spanish mackerel), whereas for the period of 1980-1984 the State of Ceará had the most outstanding deliveries in the country, with about $41 \%$ of the total fish unloaded (Fonteles-Filho, 1988). However, on the northern coast, the output has exceeded more than one half of that of the Northeast in the past five years, with approximately $52 \%$ of the country output. During the period of 1998 through 2004 , there has been a decline in production from 12.6 to 6.6 thousand tons in the Northern (State of Pará), and in this latter year those species accounted for the third highest exploited resource $(7.4 \%)$ of all marine and estuary fish in the above mentioned region (CEPNOR/IBAMA, 2006).

There are clear signs of stock decline in the northeastern region and, furthermore, those populations are probably close to the maximum limit of exploitation for a sustainable yield (Nóbrega, 2002). In other regions, such as in Mexico, Arreguín-Sanchez (1995) has reported indications of over-exploitation of $S$. cavalla, although agencies in charge of fishing management do not currently assume such a status for this species as there are effective management policies for the region (Gold and De Vries, 2002).

Phylogeographical studies have been conducted on S. cavalla in the USA and Gulf of Mexico based on migration, mark-and-recapture, and otolith shape analysis (Fable et al., 1987; Sutter et al., 1991; Schaefer and Fable, 1994), wherein results suggest that there is a stock in the southwest portion of the USA and another one in the Gulf (Johnson et al., 1993; Gold et al. 1997). However, microsatellite data (Broughton et al., 2002; Gold and De Vries, 2002) suggest that the population of the Florida Keys could not be assigned unequivocally to either genetic stock, and thus the data are not consistent with the current spatial-temporal barriers that are attributed by the management agencies (Gulf of Mexico Fishing Management Council-GMFMC). Yet, plans currently implemented by GMFMC, under whose jurisdiction is also the fishing carried out in southwestern USA, still consider the two above referred stocks.

There is no study regarding the genetic variability of this important fishing item on the coast of South America and, given that there is indication of over-exploitation in the Northeast, as well as the reduced fishing of S. cavalla and $S$. brasiliensis in Northern Brazil, the present study aimed to investigate the genetic variability of $S$. cavalla in these regions, through the analysis of the D-loop region of the mitochondrial DNA.

\section{Material and Methods}

\subsection{Sampling}

A total of 64 samples of $S$. cavalla were collected in three cities of the northern and northeastern coast of Brazil: 17 from Macapá (Amapá State), 23 from
Bragança (Pará State), and 24 from Fortaleza (Ceará State) (Figure 1). The samples from Macapá and Bragança were collected from fish unloaded as industrial catch, whereas the ones from Fortaleza came out of subsistence fishing catch.

\subsection{DNA extraction, PCR amplifying and sequencing}

Total DNA was extracted from muscle tissues of all samples using the standard method of phenol-chloroform, followed by precipitation by sodium acetate (Sambrook et al., 1989). The primers used for amplification of the D-loop mitochondrial DNA (mtDNA) region were designed for this study based on sequences of Perciformes obtained in the Genebank: L1 (5'-CCT AAC TCC CAA AGC TAG (GT) AT TC -3') and H1 (5'-TGT TTA TCA CTG CTG (AG) (AG) T TCC CT -3'). The PCR was performed on a thermocycler using in each reaction, $10 \mathrm{ng}$ of genome DNA, $10 \mathrm{nM}$ Tris-HCI pH 8.85, $25 \mathrm{mM}$ $\mathrm{KCl}, 5 \mathrm{mM}\left(\mathrm{NH}_{4}\right)_{2} \mathrm{SO}_{4}, 0.2 \mathrm{nM}$ of dNTP, $5 \mathrm{pM}$ of each primer, and 1 unit of Taq DNA polymerase (Invitrogen). The utilized program was composed of an initial cycle of $94{ }^{\circ} \mathrm{C}$ for 3 minutes, followed by 30 cycles of $94{ }^{\circ} \mathrm{C}$ for 1 minute, $50{ }^{\circ} \mathrm{C}$ for 1 minute, $72{ }^{\circ} \mathrm{C}$ for 1 minute, with a final extension period of $72{ }^{\circ} \mathrm{C}$ for 5 minute. A re-amplification was performed with the same reagent concentrations, as well as the same program, utilizing, however, the amplified DNA samples, the L1 primer, and another internal one, Perc 12S 1R (5'- GCG GAT ACT TGC ATG TGT AA -3'). Re-amplification products were then sequenced using the "dynamic dye terminator cycle sequencing" kit in the automated sequencer ABI 377, in accordance to the protocols supplied by the manufactur-
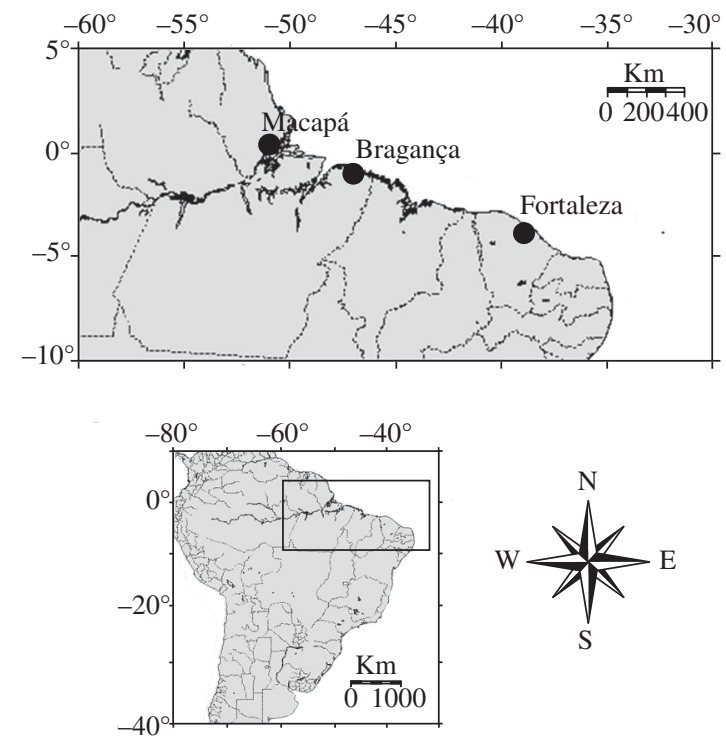

Figure 1. Map of the Brazilian Coast, showing the sample points in the Northern and Northeastern coast (Base map was created at Online Map Creation, www.aquarius.geomar. de/omc/) 
ers (Applied Biosystems, Foster, CA, USA), utilizing only the primer Perc $12 \mathrm{~S} 1 \mathrm{R}$ (all the samples were sequenced twice for variable sites confirmation).

\subsection{Population analyses}

Sequences were aligned using the CLUSTAL W program (Thompson et al., 1994) implemented in the BIOEDIT program (Hall, 1999). Deletions resulting from the alignment were handled as lost data and not included in the analyses.

Phylogenetic relationships among mitochondrial haplotypes were obtained through PAUP* 4.0b10 (Swofford, 2002) using neighbor joining, maximum likelihood, and maximum parsimony methods. The program Modeltest 3.06 (Posada and Crandall, 1998) was used to select the best evolutionary model fitting the data set. The program Network 4.2 (Bandelt et al., 1999) was utilized for construction of the haplotype network. The genetic divergence within (intra haplotypes) and between pairs of populations was calculated on Mega 3.1 (Kumar et al., 2004).

The genetic diversity, haplotype (h; Nei, 1987), and nucleotide diversities ( $\pi$; Nei 1987) were calculated on Arlequin 3.1 (http://cmpg.unibe.ch/software/arlequin3) and on DNAsp 4.0 (Rozas et al., 2003). Pairwise genetic divergences between populations were estimated using the $\mathrm{F}_{\mathrm{st}}$ (Excoffier et al., 1992) and the test significance was tested by 10,000 permutations. Partitioning of genetic variability among populations was tested using hierarchical analysis of molecular variance, AMOVA (Excoffier et al., 1992) implemented in Arlequin 3.01.

Inferences on demographic history of $S$. cavalla samples were analyzed through mismatch distribution (Slatkin and Hudson, 1991; Rogers and Harpending, 1992). The result of the distribution was tested against the population growth-decline or constant population size model implemented on DNAsp 4.0 and Arlequin 3.1. The parameters $\theta_{0}, \theta_{1}(\theta$ before and after population growth), and $\tau$ (date of the growth in units of mutational time) (Schneider and Excoffier, 1999), as well as their confidence intervals were estimated on Arlequin 3.1. In addition, Fu's Fs test (Fu, 1996, 1997) was carried out in order to ascertain possible neutrality deviations, as well as to infer population dynamics on Arlequin 3.1.

\section{Results}

Sequences of a total of 380 base pairs (bp) of the 3' D-Loop region were obtained from 64 samples of $S$. cavalla of three different localities (Macapá, Bragança, and Fortaleza). Twelve variable sites (only one transversion), seven parsimonious ones (not including deletions), and a total of 14 haplotypes were identified (Table 1) (GenBank accession numbers: EU117391 - EU117404).

The genetic diversities and neutrality tests for the samples of the analyzed localities, as well as for the entire sample are presented on Table 2. It was ascertained that the Macapá, Fortaleza, and the entire sam-
Table 1. Variable nucleotide sites within a $380 \mathrm{bp}$ amplified region of the mtDNA of Scomberomorus cavalla. BG means Bragança, MP Macapá, and FO Fortaleza.

\begin{tabular}{|c|c|c|}
\hline Haplotypes & Position/Sites & $\begin{array}{c}\text { Number of } \\
\text { samples }\end{array}$ \\
\hline & 222222222222 & \\
\hline & 122334566799 & \\
\hline & 636494456015 & \\
\hline H_1 & GACTTCAGTAAC & $2(1 \mathrm{BG}, 1 \mathrm{MP})$ \\
\hline H_2 & . TC.T.ACGGG & 1 (1 MP) \\
\hline H_3 & . TC.T.A.GGG & $\begin{array}{c}5(1 \mathrm{BG}, \\
2 \mathrm{MP}, 2 \mathrm{FO})\end{array}$ \\
\hline H_4 & .TC.T.A.G.G & $\begin{array}{c}16(4 \mathrm{BG}, \\
8 \mathrm{MP}, 4 \mathrm{FO})\end{array}$ \\
\hline H_5 & $\ldots \subset \ldots \ldots$ & 1 (1 MP) \\
\hline H_6 & $\ldots \mathrm{TC} \ldots \mathrm{A} \cdot \mathrm{G} \cdot \mathrm{G}$ & $\begin{array}{c}31(15 \mathrm{BG}, \\
4 \mathrm{MP}, 12 \mathrm{FO})\end{array}$ \\
\hline H_7 & .GTC.T.A.G.G & 1 (1 MP) \\
\hline H_8 & . TCCT.A.G.G & $1(1 \mathrm{BG})$ \\
\hline H_9 & $\ldots \ldots \ldots \mathrm{T}$ & $1(1 \mathrm{FO})$ \\
\hline H_10 & $\ldots \mathrm{TC} . \mathrm{T} . \mathrm{A} \ldots \mathrm{G}$ & $1(1 \mathrm{FO})$ \\
\hline H_11 & .T.T.A.G.G & $1(1 \mathrm{FO})$ \\
\hline H_12 & $\ldots \ldots \ldots G$ & $1(1 \mathrm{FO})$ \\
\hline H_13 & A.TC.T.A.G.G & $1(1 \mathrm{FO})$ \\
\hline H_14 & ..TC.TGA.GGG & $1(1 \mathrm{FO})$ \\
\hline
\end{tabular}

ple presented haplotype and nucleotide diversities above $70 \%$ and $0.5 \%$, respectively. However, analyses on the Bragança samples showed moderate haplotype diversity values (0.55) and low levels of nucleotide diversities. Regarding the neutrality test, Fs values were not significant in any of the analyzed localities, except for the entire population and Fortaleza in which we found a negative and significant value.

Phylogenetic analysis (the selected model by Modeltest was the HKY85 $+\mathrm{I}+\mathrm{G}-$ Base $=(0.3100$ $0.18200 .2214)$, Nst $=2$, TRatio $=7.8242$, Rates $=$ gamma, Shape $=0.0001$, Pinvar $=0.7565$ ) obtained by the three utilized methods generated similar trees in which basically only one branch was supported in all analyses by values higher than $80 \%$ of bootstrap, while the other present low levels (Figure 2a). On such trees, the clade composed by haplotypes H_1, H_5, H_9 and H_12 is sister group of the clade made up by the remaining haplotypes. Genetic divergence among haplotypes using the Kimura two parameter algorithm varied between 0.3 and $2.1 \%$; however, the divergence between the two haplotype groups was of $1.4 \%$ (data not shown).

On the haplotype network (Figure 2b), two well represented haplotypes were noticed (H_4 and H_6), whereas the other ones are singletons or shared by two individuals (except H_3, shared by 5 individuals). Closer haplotypes are singled out by no more than two mutations. It is important to highlight that no separation in groups of 
Table 2. Haplotype diversity, nucleotide diversity, and the neutrality test (Fs) of the analyzed Scomberomorus cavalla populations.

\begin{tabular}{lccccc}
\hline \multicolumn{1}{c}{ Populations } & $\mathbf{n}$ & $\mathbf{N H}$ & $\mathbf{h}$ & $\pi$ & Fs \\
\hline Macapá & 17 & 7 & $0.794 \pm 0.783$ & $0.005 \pm 0.004$ & -1.52 \\
Bragança & 23 & 5 & $0.545 \pm 0.104$ & $0.003 \pm 0.002$ & -0.808 \\
Fortaleza & 24 & 9 & $0.735 \pm 0.087$ & $0.005 \pm 0.003$ & $-3.28^{*}$ \\
Total & 64 & 14 & $0.704 \pm 0.0469$ & $0.005 \pm 0.004$ & $-6.72^{* *}$
\end{tabular}

$\mathrm{n}=$ samples; $\mathrm{NH}=$ Number of haplotypes; $\mathrm{h}=$ haplotype diversity; $\pi=$ nucleotide diversity; Fs $=$ Fu's Fs test. $* \mathrm{P}<0.05$, $* * \mathrm{P}<0.05$.
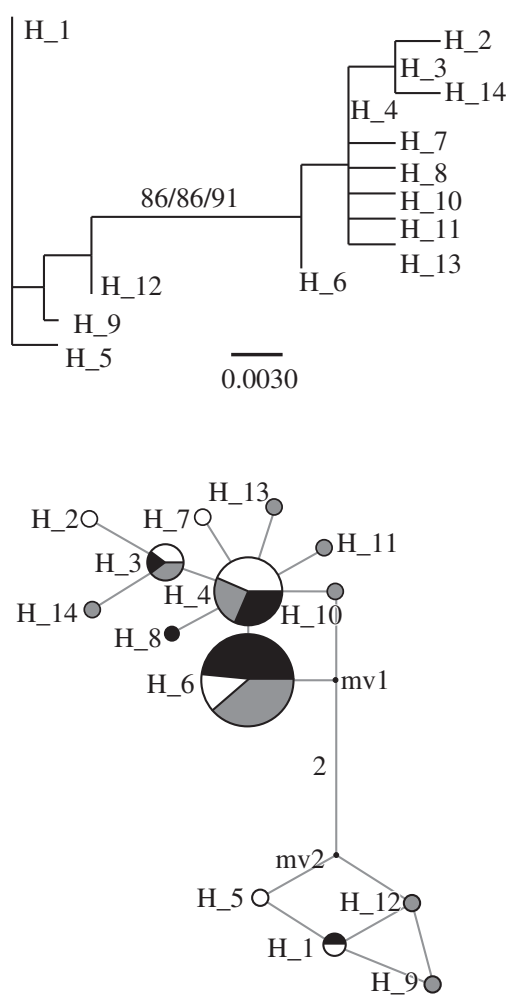

Figure 2. a) Maximum likelihood tree $(-\ln \mathrm{L}=-620.322)$ with bootstrap values (maximum parsimony/likelihood/ neighbor joining); and b) Median-joining haplotype network. The haplotypes are represented by circles, with the width proportional to their frequencies. Each branch corresponds to a single mutation, except between the median vectors (mv1 and 2), which possess two mutations (represented in this branch). Black circles correspond to Bragança samples, white to Macapá, and gray to Fortaleza.

geographic samples was noticed (Macapá, Bragança, and Fortaleza), and that the most representative haplotypes are found in all three localities. This is reaffirmed by analyses of population differentiation, in which the values of $\mathrm{F}_{\mathrm{st}}$ obtained for the localities were not significant (data not shown), as well as in the AMOVA (Table 3), since there is no structuring among the samples. Most of the variation lies in the differences within each locality, that is, basically, the existing variation that arises from the variability of each of the three sampled localities.

For the analysis of population demographic expansion, in accordance with prior data, only the entire data was utilized, and the graph of mismatch distribution shows a bimodal curve (Figure 3 ). The second observed mode, with low frequency, is a result of the most divergent samples composed by the haplotypes previously distinguished on the phylogenetic tree. In regards to the expansion parameters, values of $\theta_{0}$ and $\theta_{1}$ are not statistically different, which denies the population expansion hypothesis (data not shown).

\section{Discussion}

In the present study, according to the differentiation analyses of the samples, the non significant values of $\mathrm{F}_{\text {st }}$ show that there is an intense genetic flow among the analyzed samples. This is confirmed by AMOVA, as well as by haplotype network and phylogenetic analyses, wherein there is no assemblage of haplogroups or clades bounded by regional localities. Besides the geographical distance among the states of Amapá, Pará, and Ceará, S. cavalla is a pelagic species that possesses high performance in locomotion, which provides it with a great migrating ability (Walters, 1962). Interestingly, the phylogenetic analyses, haplotype networks as well as mismatch distribution, evidenced two haplogroups. This may be the result of haplotype presence from other populations in the northern hemisphere (or other regions), by the extinction of intermediate haplotypes between the two groups, or simply that these intermediate haplotypes were not sampled.

Besides the moderate values of haplotype diversity and low values of nucleotide diversity found for the entire sample, it is interesting to note that the great majority of mutations correspond to transitions, which added up to the number of mutations among haplotypes (usually one single mutation differentiating them) may be characteristic of a relatively recent evolutionary process. According to Grant and Bowen (1998), high values of h (above 0.5 ) and low values of $\pi$ (below 1\%) arise on populations that have suffered a bottleneck followed by population growth and accumulation of mutations. Such a condition is attributed to expansion after a period of actual low population size (Avise et al., 1984; Rogers and Harpending, 1992). However, in spite of the negative 
Table 3. Results of AMOVA with different population structures.

\begin{tabular}{ccccc}
\hline Structure/Source of variation & Variance & \% of variation & F statistics & P value \\
\hline (Macapá, Bragança and Fortaleza) & & & & $>0.05$ \\
\hline Among populations & 0.008 & 1.02 & $\mathrm{~F}_{\mathrm{st}}=0.01$ & \\
Within populations & 0.788 & 98.98 & & \\
\hline (Macapá and Bragança) (Fortaleza) & & & & \\
\hline Among groups & -0.048 & -6.24 & $\mathrm{~F}_{\mathrm{ct}}=-0.06$ \\
Among populations within & -0.043 & -5.48 & $\mathrm{~F}_{\mathrm{sc}}=0.05$ & \\
groups & 0.788 & 100.77 & $\mathrm{~F}_{\mathrm{st}}=-0.01$ & \\
Within populations & &
\end{tabular}

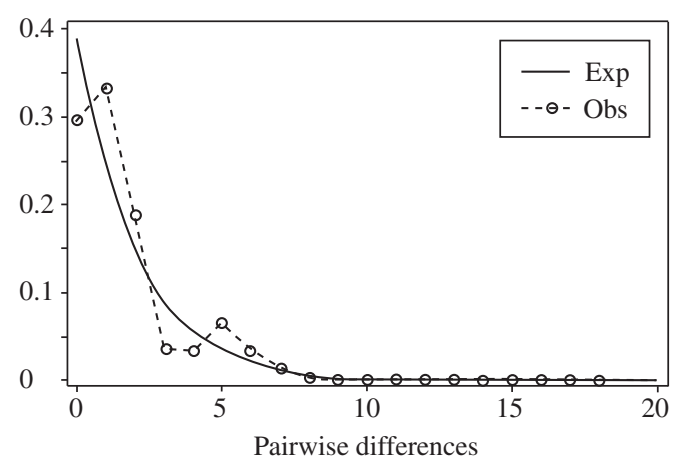

Figure 3. Mismatch distribution of the 64 mtDNA D-loop sequences of $S$. cavalla under a constant population size model (expected values). Exp and Obs means expected and observed values, respectively.

value of Fs, the values of $\theta_{0}$ and $\theta_{1}$ are not statistically different, that is, the effective population size before and after a possible expansion do not differ, thus denying the demographic expansion hypothesis.

These results also could indicate that the entire sample is undergoing some other type of evolutionary process, deviating from the neutral model of molecular evolution, such as hitchhiking or selection. However, although models point towards such processes, interpretation of the results may become confounding due to the complexity of evolution events acting upon the evolutionary time scale (Tajima, 1989). That is, different processes may leave the same markers in DNA sequences.

As there are instances of over-exploitation of S. cavalla stocks in the Brazilian territory (Nóbrega, 2002), the data herein may indeed be indicative of overfishing. The fact that the entire sample bears a moderate value of haplotype diversity may be explained by the condition that in a bottleneck process usually the impact will be greater on the allelic diversity (only 14 alleles were found) than over the heterozygosity (or heterogeneity) (Frankham et al., 2004).

The obtained results in this study show that the analyzed samples represent a single panmitic population, which presents moderate values of haplotype diversity and low nucleotide diversity. Such results ought to be taken into consideration in future management plans, since such a level of variability may compromise population stock in the future, which has already been suggested to be undergoing an overfishing status (Nóbrega, 2002). Future management actions for the northern and northeastern regions are evidenced as necessary in order to prevent this "over-exploitation". Lack of action for a sustainable management of $S$. cavalla fishing, as occurred in other countries, may impact the stocks and compromise their evolutionary potential.

Acknowledgments - This study was supported by CNPqPADCT/MCT (Millenium Project, grant N. 62.0052/01-5) and CT-Hidro/CNPq (N. 0552621/2005-5).

\section{References}

ARREGUÍN-SÁNCHEZ, S., 1995. Population dynamics of the king (Scomberomorus cavalla) of Campeche Bank, Mexico. Sci. Mar., vol. 59, no. 3-4, p. 637-645.

AVISE, JC., NEIGEL, JE. and ARNOLD, J., 1984. Demographic influences on mitochondrial DNA lineage survivorship in animal populations. J. Mol. Evol., vol. 20, no. 20, p. 99-105.

BANDELT, HJ., FORSTER, P. and ROHL, A., 1999. Medianjoining networks for inferring intraspecific phylogenies. Mol. Biol. Evol., vol. 16, no. 1, p. 37-48.

BROUGHTON, RE., STEWART, LB. and GOLD, JR., 2002. Microsatellite variation suggests substantial gene flow between king mackerel (Scomberomorus cavalla) in the western Atlantic Ocean and Gulf of Mexico. Fish. Res., vol. 54, no. 3, p. $305-316$

CARVALHO-FILHO, A., 1999. Peixes: costa brasileira. $3^{\mathrm{a}}$ edição. São Paulo, Editora Melro, 320p.

CEPNOR/IBAMA - Centro de Pesquisa e Gestão de Recursos Pesqueiros do Litoral Norte, 2006. www.ibama.gov.br/cepnor/ index.php?id_menu=52 [Access: January 23, 2006].

CERVIGÓN, F., CAPRIANI, F., FISCHER, W., GARIBALDI, L., HENDRICKX, M., LEMUS, AJ., MÁRQUEZ, R., POUTIERS, JM., ROBAINA, G. and Rodriguez, B., 1993. Field Guide to the Commercial marine and Brackish-water Resources of the Northern Coast of South America. FAO species identification sheets for fishery purpose. Rome FAO, 513p.

COLlETE, BB. and NAUEN, CE., 1983. Scombrids of the world. FAO. Fish Sinopses, vol. 125, no. 2, p. 1-37 
DEUEL, DG., 1973. The 1970 salt-water angling survey. U.S. Department of Commerce, National Marine Fisheries Service, Curent Fishery Statistics Number, vol. 6200, 54p.

DEUEL, DG. and CLARK, JR., 1968. The 1965 salt-water angling survey. U.S. Department of the Interior, Fish and Wildlife Service, Resource Publication vol. 67, 51p.

EXCOFFIER, L., SMOUSE, PE. and QUATTRO, JM., 1992. Analysis of molecular variance inferred from metric distances among DNA haplotypes: application to human mitochondrial DNA restriction data. Genetics, vol. 131, no. 2, p. 479-491.

FABLE, WA., TRENT, GW. and ELLSWORTH, SW., 1987. Movements of king mackerel, Scomberomorus cavalla, tagged in southeast Louisiana, 1983-1985. Mar. Fish. Ver., vol. 49, no. 2, p. $98-101$.

FONTELES-FILHO, A., 1988. Sinopse de informações sobre a cavala, Scomberomorus cavalla (Cuvier) e a serra, S. brasiliensis Collette, Russo and Zavalla-Camim (Pisces: Scomberomorus) no estado do Ceará, Brasil. Arq. Ciên. Mar, vol. 27, p. 21-48.

FRANKHAM, R., BALLOU, J., BRISCOE, D. and MCINNES, KH., 2004. A primer of conservation genetics. Cambridge, Cambridge University Press, 617p.

FU, YX., 1996. New statistical tests of neutrality for DNA samples from a population. Genetics, vol. 143, no. 1, p. $557-570$.

-, 1997. Statistical tests of neutrality of mutations against population growth, hitchhiking and background selection. Genetics, vol. 147, no. 2, p. 915-925.

GOLD, JR., PAK, E. and DE VRIES, DA., 2002. Population structure of king mackerel (Scomberomorus cavalla) around Peninsular Florida, as revealed by microssatelite DNA. Fish. Bull., vol. 100, no. 3, p. 491-509.

GOLD, JR., KRISTMUNDSDÓHIR, AY. and RICHARDSON, LR., 1997. Mitochondrial DNA variation in king mackerel (Scomberomorus cavalla) from the western Atlantic Ocean and Gulf of Mexico. Mar. Bio., vol. 129, no. 2, p. 221-232.

GRANT, WS. and BOWEN, BW., 1998. Shallow population histories in deep evolutionary lineages of marine fishes: Insights from sardines and anchovies and lessons for conservation. $J$. Hered., vol. 89, no.5, p. 415-426.

HALL, TA., 1999. BioEdit: a user-friendly biological sequence alignment editor and analysis program for Windows 95/98/NT. Nucl. Acids. Symp. Ser., vol. 41, p. 95-98.

JOHNSON, AG., FABLE JR., WA., GRIMES, CB. and TRENT, L., 1993. Evidence for distinct stocks of king mackerel, Scomberomorus cavalla in the Gulf of Mexico. Fish. Bull., vol. 92, no. 1, p. 92-101.

KUMAR, S., TAMURA, K. and NEI, M., 2004. Mega3: Integrated Software for Molecular Evolutionary Genetics Analysis and Sequence Alignment. Bioinformatics, vol. 5, no. 2 p. $150-163$.

MANOOCH III, CS., 1979. Recreational and commercial fisheries for king mackerel, Scomberomorus cavalla, in the South Atlantic Bight and Gulf of Mexico, USA. In Proceedings of the
Colloquium on the Spanish and King Mackerel Resources of the Gulf of Mexico. Edited by NAKAMURA, EL. and BULLIS, Jr. HR. Publ. Gulf States Mar. Fish. Comm., vol. 4, p. 33-41

NEI, M., 1987. Molecular Evolutionary Genetics. New York, USA, Columbia University Press, 512p.

NÓBREGA, FM., 2002. Idade, crescimento e avaliação de estoques da serra Scomberomorus brasiliensis (Teleostei: Scombridae), na plataforma continental do nordeste do Brasil. (Dissertação de Mestrado) - Universidade Federal Pernambuco, Recife, PE.

POSADA, D. and CRANDALL, KA., 1998. MODELTEST: testing the model of DNA substitution. Bioinf., vol. 14, no. 9, p. 817-818.

ROGERS, AR. and HARPENDING, H., 1992. Population growth makes waves in the distribution of pairwise genetic differences. Mol. Biol. Evol., vol. 9, no. 3, p. 552-569.

ROZAS, J., SÁNCHEZ-DELBARRIO, JC., MESSEGUER, X. and ROZAS, R., 2003. DnaSP: DNA polymorphism analyses by the coalescent and other methods. Bioinformatics, vol. 19, no. 18 , p. 2496-2497.

SAMBROOK, J., FRITSCH, EF. AND MANIATIS, T., 1989. Molecular cloning: a laboratory manual. $2^{\text {nd }}$. ed. Cold Spring Harbor Laboratory, New York, Could Spring Harbor Laboratory Press, 1659p.

SCHAEFER, HC. and FABLE JR., WA., 1994. King mackerel, Scomberomorus cavalla, mark-recapture studies off Florida's east coast. Mar. Fish. Rev., vol. 56, no. 3, p. 13-23.

SCHNEIDER, S. and EXCOFFIER, L., 1999. Estimation of past demographic parameters from the distribution of pairwise distances when the mutation rates vary among sites: application to human mitochondrial DNA. Genetics, vol. 152, no. 3, p. $1079-1089$.

SLATKIN, M. and HUDSON, RR., 1991. Pairwise comparisons of mitochondrial-DNA sequences in stable and exponentially growing populations. Genetics, vol. 129, no. 2, p. 555-562.

SUTTER, FC., WILLIAMS, RO. and GODCHARLES, MF., 1991. Movement patterns of stock affinities of king mackerel in the southeastern United States. Fish. Bull., vol. 89, no. 2, p. 315-324.

SWOFFORD, DL., 2002. PAUP: Phylogenetic Analysis Using Parsimony and other Methods Version 4. Sundeland, Massachusetts: Sinauer Associates, Inc. Publisher.

TAJIMA, F., 1989, Statistical method for testing the neutral mutation hypothesis by DNA Polymorphism. Genetics, vol. 123, no. 3 , p. $585-595$.

THOMPSON, JD., HIGGINS, DG. and GIBSON, TJ., 1994. Clustal W: improving the sensitivity of progressive multiple sequence alignment through sequence weighting, positionspecific gap penalties and weight matrix choice. Nucleic Acids Res., vol. 22, no. 22, p. 4673-4680.

WALTERS, V., 1962. Body form and swimming performance in the scombrid fishes. Am. Zool., vol. 2, no. 2, p. 143-149. 